\title{
Immunochemical Evidence for Protein Abnormalities in Platelets from Patients with Glanzmann's Thrombasthenia and Bernard-Soulier Syndrome
}

\author{
Inger Hagen, Alan Nurden, Ole Jannik Bjerrum, Nils Olav Solum, and \\ JaCQUES CAEN, Research Institute for Internal Medicine, Section on \\ Thrombosis and Haemostasis, Rikshospitalet, Oslo 1, Norway; \\ U 150 Institut National de la Santé et de la Recherche Medicale, \\ Hopital Lariboisiere, Paris 10, France; The Protein Laboratory, \\ University of Copenhagen, Copenhagen, Denmark
}

\begin{abstract}
A B S T R A C T Crossed immunoelectrophoresis of Triton X-100 solubilized proteins from normal and abnormal platelets was performed with rabbit antibodies raised against normal platelets. In Bernard-Soulier platelets protein 13 was not detected, and neither the amphiphilic (probably GP Ib) nor the hydrophilic (glycocalicin) glycocalicin-related proteins were seen when monospecific antiglycocalicin antiserum was used. The most prominent precipitate, 16 , and platelet fibrinogen, 24 were not detected in platelets of two patients with type I thrombasthenia, whereas in one patient with type II thrombasthenia fibrinogen was clearly detected, but the amount of protein 16 remained severely reduced. Protein 16 was heavily labeled after lactoperoxidase-catalyzed ${ }^{125}$ I iodination of normal platelets, and was precipitated by IgG-L, an alloantibody from a polytransfused thrombasthenic patient. Sodium dodecyl sulfate-polyacrylamide gel electrophoresis (SDS-PAGE) or protein 16 cut out from immunoplates showed two ${ }^{125}$ I-labeled glycoprotein bands, which migrate as GP IIb and GP IIIa. SDS-PAGE of ${ }^{125} \mathrm{I}$ labeled type I thrombasthenic platelets showed no periodic acid-Schiff bands or peaks of radioactivity in the GP IIb and GP IIIa regions, whereas in the GP I region both the periodic acid-Schiff band intensity and the radiolabeling were within the normal range. Autoradiography after crossed immunoelectrophoresis of iodinated thrombasthenic platelets showed that the bulk of radioactivity was bound to protein 17 . This glycoprotein, which was also present in normal and Bernard-Soulier platelets, migrates in the GP I region on SDS-PAGE. Thus, the bulk of radioactivity ob-
\end{abstract}

Received for publication 18 June 1.979 and in revised form 25 September 1979. served in the GP I region after SDS-PAGE is associated with protein 17 and not with glycocalicin.

\section{INTRODUCTION}

Blood platelets play a crucial role in hemostasis by adhering to the exposed subendothelial tissue at the site of the vessel wall injury, followed by aggregate formation caused by the synthesis of prostaglandin metabolites and the secretion of intracellularly stored ADP. The Bernard-Soulier syndrome and Glanzmann's thrombasthenia are inherited bleeding disorders resulting from an impaired platelet function (1-3). Bernard-Soulier platelets tend to be of an increased size on blood smears, do not adhere normally to subendothelial tissue, and do not agglutinate in the factor VIII-dependent systems. However, they do undergo the release reaction upon thrombin stimulation and aggregate with ADP. In contrast, thrombasthenic platelets do not aggregate with ADP, but the adhesion to subendothelial tissue, the release reaction, and the factor VIII-dependent agglutination occur normally or relatively normally. In type I thrombasthenia no clot retraction occurs, and the platelets contain little or no fibrinogen. In type II thrombasthenia clot retraction is present but reduced ( $\sim 50 \%$ of normal), the platelet fibrinogen content is normal, but the platelet ATP content reduced (recent reviews on the platelet defects in the Bernard-Soulier syndrome and thrombasthenia; 4, 5).

Studies on Bernard-Soulier and thrombasthenic platelets may, therefore, be useful in detecting factors that are essential for normal platelet functions. A membrane defect in Bernard-Soulier platelets was first suggested by Grottum and Solum (6) who found a reduced electrophoretic mobility combined with a re- 
duced content of sialic acid per unit surface area of these cells. Comparison of the glycoprotein composition of normal and Bernard-Soulier platelets by sodium dodecyl sulfate-polyacrylamide gel electrophoresis (SDS-PAGE) ${ }^{1}$ have further shown a reduced periodic acid-Schiff (PAS) stain intensity of a 155,000 mol wt glycoprotein (GP I region) in Bernard-Soulier platelets (7), and glycocalicin (GPS or GP Is) could not be detected $(8,9)$. We have found a normal pattern of protein $(7,10)$ and a normal distribution of radioactivity after SDS-PAGE of Bernard-Soulier platelets that had been labeled by lactoperoxidase-catalyzed iodination (10), whereas others have reported a grossly abnormal protein pattern and distribution of ${ }^{125} \mathrm{I}-$ labeled proteins (11).

Thrombasthenic platelets show a strongly reduced PAS stain intensity of GP IIb and GP IIIa (GP III) compared to normal $(8,12,13)$ and very little radioactivity was seen in these regions after SDS-PAGE of iodinated, thrombasthenic platelets $(10,13)$. However, SDS-PAGE is not well suited for quantitative measurements of proteins, and such an analysis is further complicated by the fact that certain proteins may comigrate in some SDS-PAGE systems $(10,14)$. Crossed immunoelectrophoresis in the presence of nonionic detergent has proved to be a useful tool in the study of membrane proteins $(15,16)$. This two-dimensional system permits qualitative characterization as well as a semi-quantitative estimate of the individual protein antigens. Crossed immunoelectrophoresis of Triton $\mathrm{X}-100$ extracts of normal platelets using corresponding rabbit antibodies has revealed more than 20 precipitates, and several of these have been characterized according to their subcellular localization, carbohydrate content, amphiphilic nature, and topography (16). In the present investigation this technique has been used to examine platelets isolated from patients with the Bernard-Soulier syndrome and Glanzmann's thrombasthenia.

\section{METHODS}

Patients. Platelets were obtained with informed consent from two Bernard-Soulier (N.V. and G.B.) and three thrombasthenic patients (M.A., A.C., and J.H.). The case history of N.V. was given by Caen et al. (7) and that of G.B. was first reported by Bernard et al. (17). Patients M.A. and A.C. will be referred to as type I thrombasthenia and J.H. as type II thrombasthenia in this paper. This classification was introduced by Caen (5) on the basis of the observed differences in clot retraction, platelet fibrinogen content, and platelet nucleotide content. Patient A.C. and patient J.H. were referred to as case 3 and case 8 in the original report of Caen et al. (2), the case history of patient M.A. has not previously been reported. Platelet function studies indicated that she was a typical type I thrombasthenia as defined by Caen (5).

${ }^{1}$ Abbreviations used in this paper: PAS, periodic acidSchiff; SDS-PAGE, sodium dodecyl sulphate-polyacrylamide gel electrophoresis.
Isolation of platelets and membranes. Human blood was anticoagulated with one-tenth of the final volume with $0.14 \mathrm{~mol} / \mathrm{liter}$ citric acid, $0.16 \mathrm{~mol} / \mathrm{liter}$ trisodium citrate, and $0.11 \mathrm{~mol} /$ liter glucose, $\mathrm{pH} 4.3$ (7). Platelet-rich plasma was obtained by centrifugation $\left(150 \mathrm{~g}, 15 \mathrm{~min}, 20^{\circ} \mathrm{C}\right)$ and the platelets washed three times by repeated centrifugation $\left(2,500 \mathrm{~g}, 10 \mathrm{~min}, 20^{\circ} \mathrm{C}\right)$ and resuspension in Tris-buffered saline, $\mathrm{pH}$ 7.4, that contained glucose, and EDTA $(0.15$ mol/liter $\mathrm{NaCl}, 0.01 \mathrm{~mol} / \mathrm{liter}$ Tris, $5 \mathrm{mmol} / \mathrm{liter}$ glucose, and $1 \mathrm{mmol} /$ liter EDTA). Platelet-rich plasma from the Bernard-Soulier patients was prepared using an Isopaque (Nyegaard \& Co., Oslo, Norway)-dextran 500 gradient as described by Bøym (18), and the platelets washed as above. The leukocyte contamination was $<1 \%$ as measured by phase-contrast microscopy. Platelet membranes were prepared by the glycerol lysis technique (19) with a $30 \%$ (wt/wt) sucrose cushion in the final centrifugation step. ${ }^{2}$

${ }^{125}$ I Iodination of platelets. Surface labeling of whole platelets was performed by lactoperoxidase-catalyzed ${ }^{125} \mathrm{I}$ iodination according to Phillips and Agin (20). Solubilization of platelet and membrane proteins were performed by suspension in 1\% Triton X-100 (Rohm and Haas Co., Philadelphia) (vol/vol) in Tris-glycine buffer, $\mathrm{pH} 8.7$ (38 mmol/liter Tris, $100 \mathrm{mmol} /$ liter glycine) followed by ultrasonication $(3 \times 5$ s) in a Branson Ultrasonifier (Branson Sonic Power Co., Danbury, Conn.) position 4 , and ultracentrifugation as described (16). $90 \%$ of the platelet proteins were solubilized by this method (16).

Preparation of antibodies. Platelet antibodies were obtained by injecting $0.2 \mathrm{ml}$ of a $1: 1$ mixture of a washed platelet suspension ( $2 \mathrm{mg}$ protein $/ \mathrm{ml}$ ) and Freund's incomplete adjuvant subcutaneously into the back of the rabbits. The antiserum collected during a 6-mo period was pooled, and the immunoglobulin fraction purified according to Harboe and Ingild (21). The final protein concentration was $46 \mathrm{mg} / \mathrm{ml}$. Antiglycocalicin antiserum was obtained by immunizing rabbits according to the scheme given by Bjerrum and $\mathrm{B} \phi \mathrm{g}$ Hansen (22) with purified glycocalicin. ${ }^{3}$ Immunoglobulin (Ig)G-L is a human antibody isolated from a polytransfused thrombasthenic patient $(\mathrm{L})$. This antibody induces a thrombasthenic-like reactivity in normal platelets $(23,24)$. The purified immunoglobulin fraction isolated from serum was kindly provided by Dr. G. Tobelem, Hôpital Saint-Louis, Paris, France.

Immunoelectrophoretic analysis. Crossed immunoelectrophoresis was performed in $1 \%$ (wt/vol) agarose gels containing $1 \%(\mathrm{vol} / \mathrm{vol})$ Triton $\mathrm{X}-100(22)$. The solubilized proteins were separated in the first dimension electrophoresis (10 V/cm, $45 \mathrm{~min})$ and immunoprecipitation took place in the antibody-containing gel $\left(500 \mu \mathrm{g} / \mathrm{cm}^{2}\right)$ during the second dimension electrophoresis $(2 \mathrm{~V} / \mathrm{cm}, 18-20 \mathrm{~h})$. Quantitation of the individual peak area was performed by planimetry (25), and the area expressed in arbitary units.

SDS-PAGE. SDS-PAGE, (T:6.2\%, C:0.32\%) of normal and thrombasthenic platelets were performed as described by Laemmli (26). Platelet samples were prepared by incubation at $37^{\circ} \mathrm{C}$ for $1 \mathrm{~h}$ in $2 \%$ SDS that contained $10 \mathrm{mmol} /$ liter Tris, $150 \mathrm{mmol} / \mathrm{liter} \mathrm{NaCl}, 3 \mathrm{mmol} / \mathrm{liter}$ EDTA, and 5 mmol/liter $N$-ethylmaleimide. Samples were reduced by incubation with $5 \%(\mathrm{vol} / \mathrm{vol}) 2$-mercaptoethanol at $37^{\circ} \mathrm{C}$ for $1 \mathrm{~h}$ before the application. Molecular weight markers were run in parallel (high molecular weight kit, Bio-Rad Laboratories, Richmond, Calif.). Solubilization of proteins in an

${ }^{2}$ Nichols, W. Personal communication.

${ }^{3}$ Solum, N. O., I. Hagen, C. Filion Myklebust, and T. Stabaek. Platelet glycocalicin: its membrane association and solubilization in aqueous media. Submitted for publication. 
immunoprecipitate was performed by incubating the gel pieces as cut from $4-8$ washed, unstained immunoplates as described above (27). Gels were stained for protein with Coomassie Brilliant Blue (28), and for carbohydrate by the PAS technique (29), and were scanned in a Vernon model PH 14 recording photometer (Vernon Integrating Photometers, Paris, France). Radioactive gels were cut into $1 \mathrm{~mm}$ pieces using a Bio-Rad Model 190 Gel Slicer, and the radioactivity in each gel piece measured in an Intertechnique CG 2000 gamma counter (Intertechnique, Placier, France).

\section{RESULTS}

Reference pattern and characterization of the proteins of normal human platelets. Crossed immunoelectrophoresis of Triton X-100 solubilized proteins from whole, normal ${ }^{125}$ I-iodinated platelets using antibodies raised against whole platelets resulted in the formation of multiple immunoprecipitates (Fig. 1A, reference pattern). Because of the higher resolution, intermediate gels were always used in the second dimension. Immunoprecipitation in intermediate gels that do not contain antibodies is a result of electroendosmosis. The reference pattern obtained in the present experiments was slightly different from the one previously observed (16). This is a result of the use of a different antibody pool. Proteins are numbered according to their position relative to the anode as described earlier (16). Autoradiographic analysis of the dried immunoplates revealed heavy labeling of protein 16 (Fig. 1B). Some radioactivity was associated with protein 17, whereas only traces of radioactivity were seen associated with protein $6,20,23$, and 24 .

To assess the reproducibility of the crossed immunoelectrophoresis procedure, the area of immunoprecipitate 6 and 16 were determined from parallel experiments using the same Triton extract. The ratio between the area of 16 and 6 was $2.10 \pm 0.08$ (mean $\pm S D$; $n=7$ ), and the individual peak areas were $45.4 \pm 12$ and $21.4 \pm 5$ arbitrary (mean $\pm \mathrm{SD}, n=7$ ) for protein 16 and 6 , respectively. The variation that occurred in the peak area was examined by crossed immunoelectrophoresis of platelet extracts from different normal donors. In this case, the ratio between the area of protein 16 and 6 was $1.88 \pm 0.43($ mean $\pm \mathrm{SD}, n=9)$.

Crossed immunoelectrophoresis of the platelet extract against antiplatelet antibodies using an intermediate gel containing a specific antiglycocalicin antiserum resulted in the formation of a double-peak immunoprecipitate corresponding to protein 13 (Fig. IC). The small, fast-migrating peak has been shown to represent the hydrophilic protein glycocalicin (GPS or GP Is) because a specific increase in the area of this peak was observed when purified glycocalicin was applied together with the Triton-solubilized platelet proteins (addition experiment). ${ }^{3}$ Crossed hydrophobicinteraction immunoelectrophoresis has demonstrated that the major, slow migrating peak of the glycocalicinrelated proteins is amphiphilic and probably represents the membrane form of glycocalicin (GP Ib). ${ }^{3}$

Crossed immunoelectrophoresis of solubilized proteins from ${ }^{125}$ I-labeled platelets showed that protein 16 formed an immunoprecipitate with the antibody isolated from a polytransfused thrombasthenic patient (IgG-L), in that the incorporation of IgG-L in the intermediate gel resulted in the specific precipitation of protein 16. (Fig. ID and E). Both the protein stain (Fig. 1D) and the autoradography (Fig. 1E) revealed that the whole of band 16 was retained in the intermediate gel. To further characterize protein 16 , this precipitate was carefully cut out from washed, unstained immunoplates. After solubilization in SDS, the material was examined by SISS-PAGE (Fig. 2). The upper curve (Fig. 2A) shows the gel scan after SDSPAGE and Coomassie Blue staining of reduced samples of protein 16. Two protein staining bands that comigrate with membrane GP IIb and GP IIIa, and with apparent mol wt of 142,000 and 114,000 (12) are seen. Both the 142,000 and the 114,000 polypeptides in the protein 16 immunoprecipitate stained positively in the PAS reaction. In the absence of disulphide bond reduction membrane GP IIb and GP IIIa show characteristic changes of migration (Fig. 2D) due to their content of inter- and intramolecular disulphide bonds (13). The two high molecular weight polypeptides in the protein 16 immunoprecipitate exhibit similar changes in their migration. (Fig. 2C). Also examination of radioactively ${ }^{125}$ I-labeled protein 16 in two different SDS-PAGE systems $(26,30)$ revealed radioactivity peaks congruent with these two glycopolypeptides demonstrating that the corresponding glycoproteins represented true platelet components and not immunoglobulins. These characteristics strongly suggest that the 142,000 and the $114,000 \mathrm{~mol}$ wt polypeptides do represent GP IIb and GP IIIa, respectively, and indicate that both membrane GP IIb and GP IIIa are true components of the protein 16 immunoprecipitate. The other bands seen in Fig. 2A and 2C may originate from the immunoglobulins in the precipitate. This assumption is supported by SDS-PAGE of the immunoglobulin preparation, and the fact that no major platelet proteins comigrate with these bands.

Bernard-Soulier syndrome. Platelets from two patients with the Bernard-Soulier syndrome were solubilized in Triton X-100 and the extract examined by crossed immunoelectrophoresis with antiplatelet antibodies. The results obtained using the platelets of G.B. are illustrated in Fig. 3. Identical results were obtained for the second patient. Protein 13 could not be detected with Bernard-Soulier platelets. Furthermore, the incorporation of the specific antiglycocalicin antiserum in the intermediate gel did not result in the formation of any immunoprecipitate. The absence 

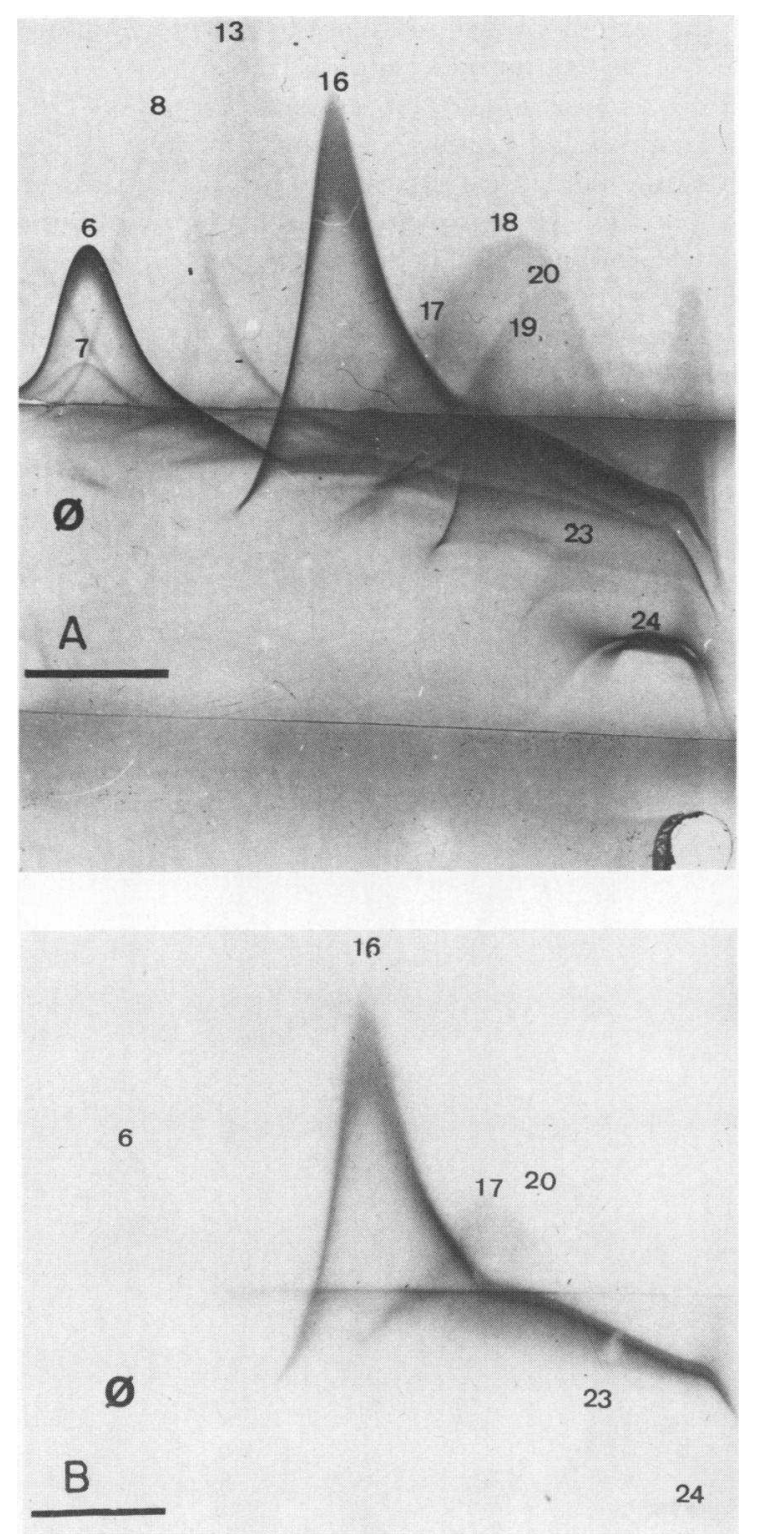

FIGURE 1 Crossed immunoelectrophoresis of $100 \mu \mathrm{g}$ normal, $\left({ }^{125} \mathrm{I}\right)$ iodinated platelet proteins solubilized in Tris/glycine buffer, $\mathrm{pH} 8.6$, that contained $1 \%$ (vol/vol) Triton X-100, using antibodies raised against whole platelets $\left(500 \mu \mathrm{g} / \mathrm{cm}^{2}\right)$. (A) Coomassie Brilliant Blue stained immunoplate (reference pattern). No antibodies were incorporated in the intermediate gel. (B) Autoradiography of the same plate as in A. (C) 400 $\mu l$ of antiglycocalicin antiserum was incorporated in the intermediate gel. (D) $400 \mu \mathrm{l}$ of IgG-L was incorporated in the intermediate gel. (E) Autoradiography of the same plate as in D. The first dimension electrophoresis was performed at $10 \mathrm{~V} / \mathrm{cm}$ for $45 \mathrm{~min}$, and the second dimension overnight at 1-2 V/cm. The electrode buffer contained $38 \mathrm{mmol} / \mathrm{liter}$ Tris and $100 \mathrm{mmol} / \mathrm{liter}$ glycine. The scale represents $1 \mathrm{~cm}$.

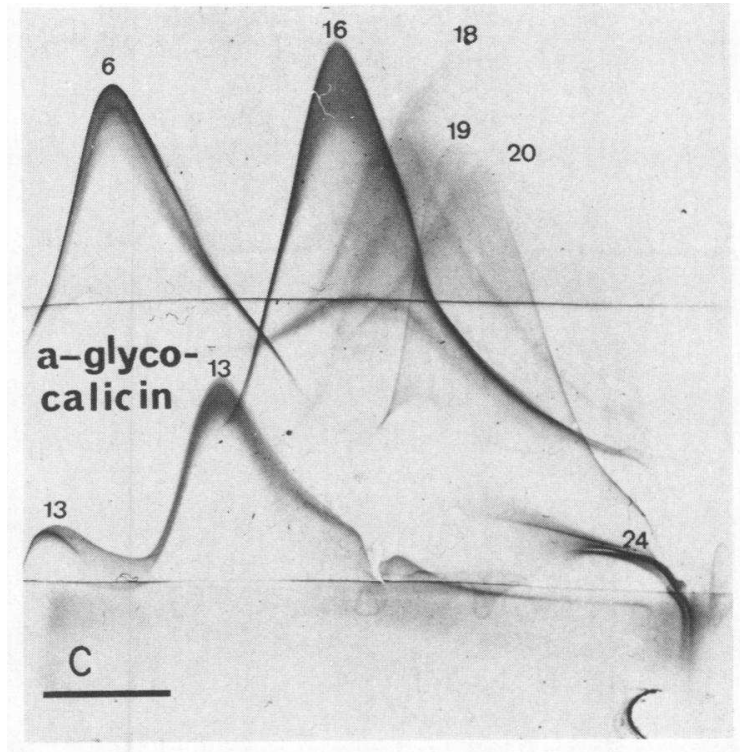

13

8
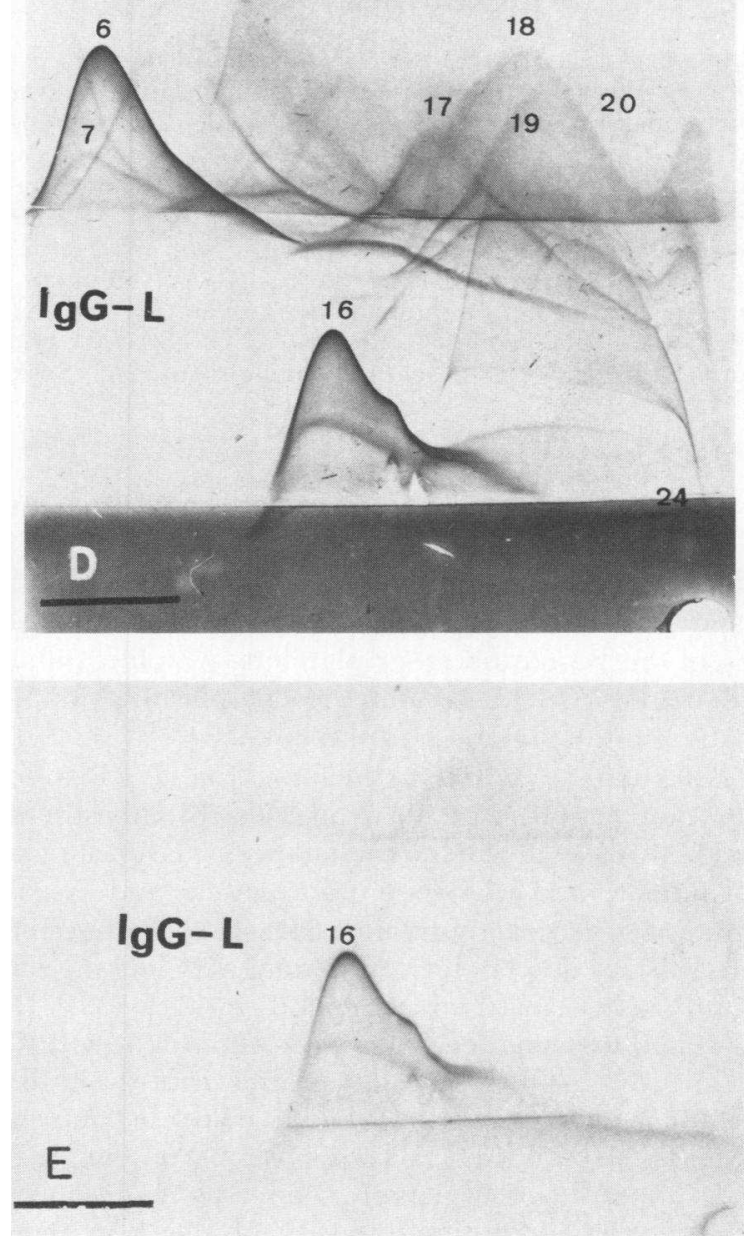


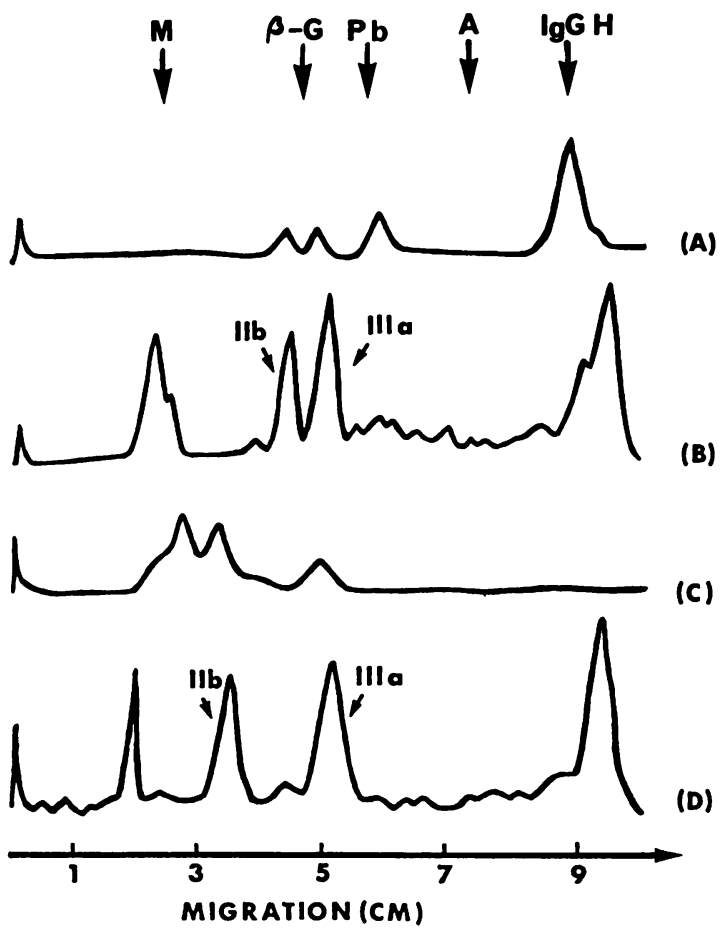

FIgure 2 Gel scans after SDS-PAGE and Coomassie Blue staining. (A and C) protein 16 cut out from unstained, washed immunoplates and (B and D) isolated platelet membranes. SDS-PAGE was performed either after reduction of disulphide bonds by $5 \%$ (vol/vol) 2-mercaptoethanol (A and B) or in the absence of disulphide bond reduction (C and D). Electrophoresis was performed with separating gels of $\mathrm{T}: 6.2 \%$; C: $0.32 \%$ (reduced samples) or T: $7.2 \%$, C: $0.32 \%$ (nonreduced samples). Molecular weight markers were: heavy-chain myosin $(\mathrm{M}, 200,000), \beta$-galactosidase $(\beta-\mathrm{G}, 130,000)$, phosphorylase $\mathrm{b}(\mathrm{Pb}, 94,000)$, bovine serum albumin $(\mathrm{A}, 68,000)$, and $\operatorname{IgGH}(50,000)$

of protein 13 was a specific abnormality, the other major immunoprecipitates were clearly detected. The reduced area below protein 16 and the other membrane proteins is probably caused by the increased size of the Bernard-Soulier platelets, which results in and increase in the amount of cytoplasmic proteins relative to the membrane components.

Glanzmann's thrombasthenia, type I. Platelets from one patient with Glanzmann's thrombasthenia, type I (M.A.) were labeled by lactoperoxidase-catalyzed ${ }^{125}$ I iodination. The glycoprotein pattern and the distribution of radioactivity after SDS-PAGE were compared to normal platelets. In normal platelets the bulk of radioactive material coincided with the GP IIIa band, and two smaller peaks were congruent with GP IIb and GP I (GP Ib and glycocalicin). In the thrombasthenic platelets no PAS bands could be detected in the GP IIb and GP IIIa regions, and no congruent peaks of radioactivity were seen. However, in the GP I region, both the intensity of the PAS bands and the extent of the radiolabeling were similar to that observed in normal platelets.

Crossed immunoelectrophoresis performed on Triton $\mathrm{X}$-100-solubilized platelet proteins from two patients with Glanzmann's thrombasthenia, type I (M.A. and A.C.) showed the absence of the major immunoprecipitate, protein 16 (Fig. 4). Furthermore, no immunoprecipitate was detected when IgG-L was incorporated in the intermediate gel. In these patients protein 24 , which has previously been identified as platelet
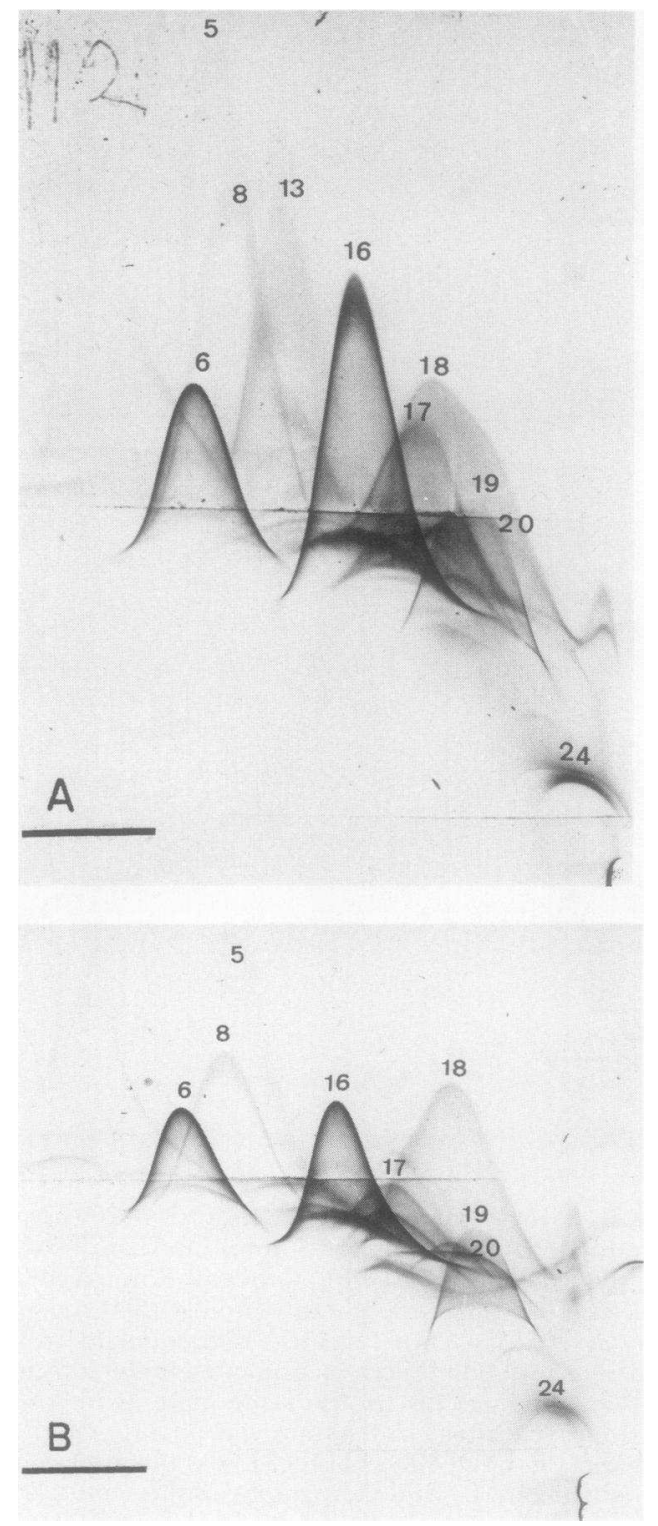

Figure 3 Crossed immunoelectrophoresis of Triton X-100 solubilized proteins from (A) normal and (B) BernardSoulier platelets (G.B.), demonstrating the absence of protein 13 in Bernard-Soulier platelets. Experimental conditions were as in Fig. 1. 


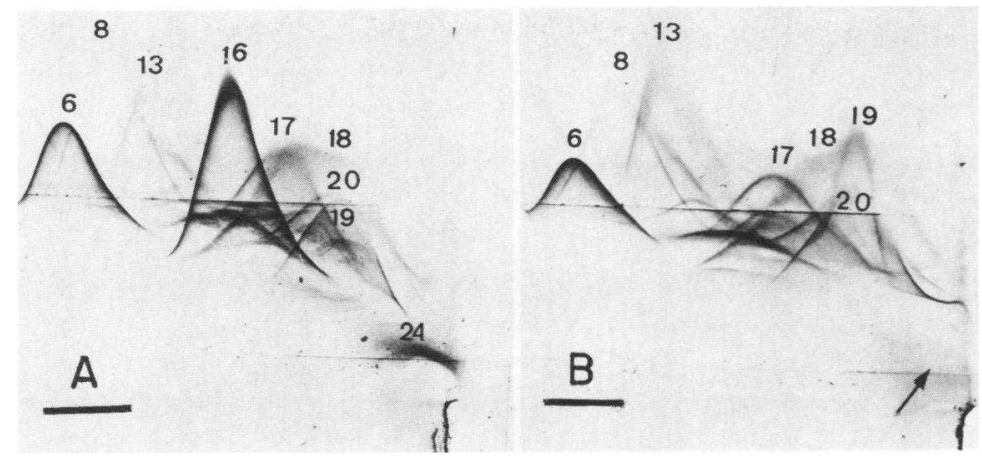

FIGURE 4 Crossed immunoelectrophoresis of Triton X-100 solubilized proteins from (A) normal platelets, and (B) type I thrombasthenic platelets (M.A.). Protein 16 and 24 were absent from the thrombasthenic platelets. Experimental conditions were as in Fig. 1.

fibrinogen (16) was absent or strongly reduced (Fig. 4 , arrow). When autoradiography of the immunoplate obtained by crossed immunoelectrophoresis of Triton $\mathrm{X}-100$-solubilized proteins from ${ }^{125} \mathrm{I}$-iodinated thrombasthenic platelets was performed, one prominent radioactive precipitate, (protein 17) was observed (Fig. $5 \mathrm{~B})$. This protein was also present in normal platelets as demonstrated by an addition experiment using a mixture of labeled thrombasthenic and unlabeled normal platelets as antigens (Fig. 5B). In this case, the area below protein 17 increased compared to that obtained with the solubilized thrombasthenic platelets alone. Protein 16 could not be detected as a precipitate by crossed immunoelectrophoresis of type I thrombasthenic platelets. However, the autoradiogram obtained from the addition experiment revealed radioactive label associated with normal protein 16 (Fig. 5B), probably due to coprecipitation with small amounts of other radioactive proteins (27).

Glanzmann's thrombasthenia, type II. The Triton X-100 extract of the platelets from one patient with Glanzmann's thrombasthenia, type II (J.H.), was examined by crossed immunoelectrophoresis (Fig. 6). In this case, fibrinogen (No. 24) was clearly detected. Furthermore, an immunoprecipitate corresponding in electrophoretic mobility to protein 16 was detected, although it showed a strongly reduced area compared to that of normal platelets. The amount of protein 16 present in type II thrombasthenic platelets was calculated by planimetry to be $13 \%$ of normal. Immunochemical identity between protein 16 from normal and type II thrombasthenic platelets has been demonstrated by precipitation with IgG-L crossed affinoimmunoelectrophoresis and crossed hydrophobic-interaction immunoelectrophoresis (31).

\section{DISCUSSION}

In this study, Triton X-100-solubilized proteins from normal and abnormal human platelets have been ex- amined by crossed immunoelectrophoresis using antibodies raised against whole, normal platelets. A further characterization of some of the individual immunoprecipitates in the normal reference pattern has been achieved, and distinct protein abnormalities in BernardSoulier and thrombasthenic platelets have been demonstrated. The absence of protein 13 and 16 in platelets from patients with Bernard-Soulier syndrome and Glanzmann's thrombasthenia type I, respectively, were specific abnormalities that were confirmed both by use of monospecific as well as with the polyspecific antibodies.

The reproducibility of the method was examined by performing several electrophoretic runs of the same platelet extract. A standard deviation of the peak area of $\pm 10 \%$ was obtained, which is in accordance with other studies on solubilized proteins (32). A greater variation between the ratio of peak 16 and 6 was observed when extracts from platelets isolated from different control donors were used. Several factors may

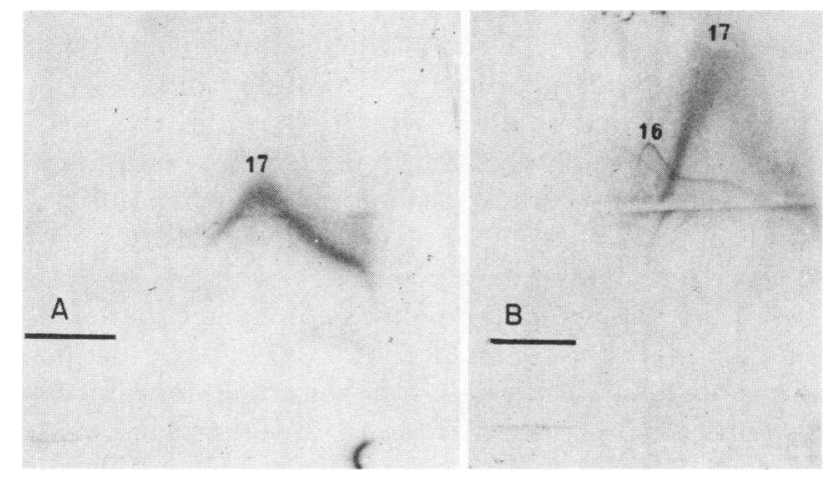

Figure 5 Autoradiography after crossed immunoelectrophoresis of Triton X-100 solubilized proteins from (A) 200 $\mu \mathrm{g}$ of ( $\left.{ }^{125} \mathrm{I}\right)$ iodinated, type I thrombasthenic platelets (M.A.) and (B) $200 \mu \mathrm{g}$ of $\left({ }^{125} \mathrm{I}\right)$ iodinated type I thrombasthenic platelets plus $150 \mu \mathrm{g}$ of unlabeled normal platelets. In (B), the area below precipitate 17 is increased compared to (A). Experimental conditions were as in Fig. 1. 


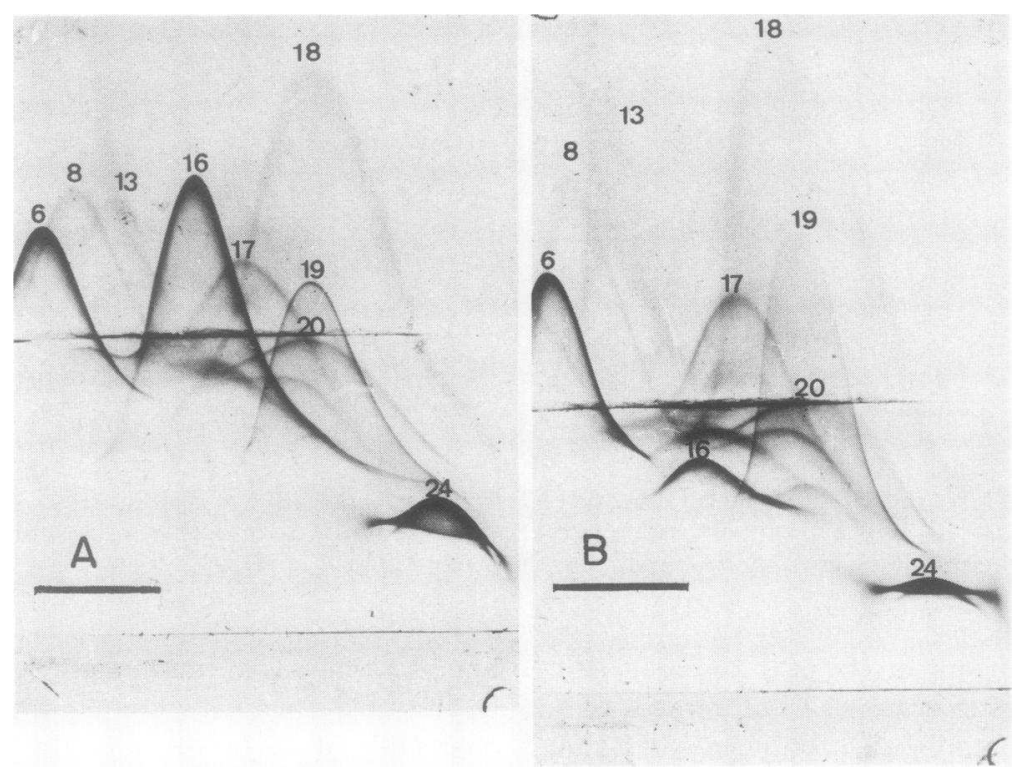

Figure 6 Crossed immunoelectrophoresis of Triton X-100-solubilized proteins from (A) normal platelets, and (B) type II thrombasthenic platelets (J.H.). Small amounts of protein 16 were detected. Experimental conditions were as in Fig. 1.

contribute to this variability, including slightly different protein concentration of the various extracts and also some differences in the volumes and amount of protein applied. Further standardization and use of more internal protein markers may reduce the variation. However, our results demonstrated that a semiquantitative estimate of the proteins can be made from the immunoplates.

Except for protein 13, most of the precipitates seen with the present antibody pool could be correlated to our previous reference pattern (16). This protein, which forms an immunoprecipitate with antiglycocalicin antiserum, was not seen in our first batch of platelet antibodies. Even with the present antibody pool the immunoprecipitate of protein 13 was weak compared to that obtained with the specific antiglycocalicin antiserum. This may indicate that antibodies to glycocalicin are not easily formed when rabbits are immunized with whole platelets. Glycocalicin is a surface membrane glycoprotein which is solubilized from the membrane during homogenization of platelets in the absence of EDTA $(30,33)$. A relationship between glycocalicin and the membrane glycoprotein GP Ib (or GP Ia as termed by others) has been suggested because the appearance of glycocalicin in the soluble fraction is linked to a markedly reduced stain intensity of GP Ib (14). We observed that protein 13 formed a double-peak immunoprecipitate with the antiglycocalicin antibody. In a recent study, Solum and co-workers have identified the fastest migrating, minor peak as the hydrophilic, soluble glycocalicin and the slowest migrating peak as an amphiphilic component that is probably the membrane form of glycocalicin and possibly identical to GP Ib. The antigenic relationship between the two proteins supports the idea that glycocalicin represents a split product of the amphiphilic membrane glycoprotein (14). A similar relationship has been demonstrated between two forms of dopamine- $\beta$-hydroxylase from bovine adrenal medulla (34).

Nachman and collaborators (35) have reported that the peptide map of the tryptic digest of purified glycocalicin was different from those obtained with two membrane glycoproteins migrating in the GP I region on SDS-PAGE (mol wt 210,000 and 150,000 ) The relationship, if any, between these two glycopolypeptides and the amphiphilic glycocalicin-related glycoprotein described in the present paper is unclear. The different starting material used in the two studies (membranes isolated by pestle homogenization vs. Triton extracts of whole platelets) and the fact that the presence of glycocalicin-related material (i.e., glycoproteins that react with monospecific antiglycocalicin antibody) in isolated membranes is dependent on the homogenization technique and the composition of the medium, make comparisons difficult at the present stage. As seen from the present work on normal, Bernard-Soulier and thrombasthenic platelets it is evident that the GP I fraction also contains glycoproteins that are unrelated to glycocalicin. If all the glycocalicin-related material is degraded and solubilized during platelet homogenization, results like 
those reported by Nachman et al. (35) would be anticipated.

Crossed immurtoelectrophoresis of solubilized platelets from two Bernard-Soulier patients showed the apparent absence of both glycocalicin and its amphiphilic form (protein 13), whereas another glycoprotein (No. 17), which migrates in the GP I region, was present. This is in accordance with the results obtained by SDS-PAGE of Bernard-Soulier platelets, which has revealed strongly reduced PAS stain intensity of GP Ib and no traces of glycocalicin (8-9). Jamieson and co-workers (36) have recently reported that GP I was present, albeit in reduced amount, in the platelets from Bernard-Soulier patients. However, a specific demonstration of the protein abnormalities in Bernard-Soulier platelets by SDS-PAGE is complicated by the fact that more glycoproteins appear in the GP I region (mol wt; 150,000).

Protein 13 is only weakly labeled after lactoperoxidase-catalyzed ${ }^{125}$ I iodination of whole platelets. The radioactive peak observed in the GP I region after SDS-PAGE of ${ }^{125}$ I-iodinated platelets is mainly associated with proteins other than glycocalicin or membrane GP Ib. This explains the normal peak of radioactivity previously seen in the GP I region after SDS-PAGE of ${ }^{125}$ I-iodinated, Bernard-Soulier platelets (10). With the exception of protein 13 , no other differences were observed between the immunoprecipitation patterns obtained with solubilized proteins from normal and Bernard-Soulier platelets. This is consistent with our previous results using SDS-PAGE $(7,10)$, and with our current studies on the analysis of the platelets of three Bernard-Soulier patients in which we used improved SDS-PAGE procedures. ${ }^{4}$

Protein 16 has previously been identified as a plasma membrane sialoglycoprotein, and a heterogeneous character of this protein was suggested on the basis of the asymmetrical appearance of the immunoprecipitate (16). SDS-PAGE of the solubilized immunoprecipitate 16, which was cut out and pooled from several immunoplates, showed two polypeptide bands that migrated congruent with GP IIb and GP IIIa and that stained positively with the PAS reagent. Several other lines of evidence support the idea that protein 16 represents GP IIb and GP IIIa. Firstly, both glycoproteins are labeled after lactoperoxidase-catalyzed iodination of whole platelets, and radioactive peaks congruent with the polypeptides were seen on SDSPAGE of protein 16 solubilized from the immunoplates obtained after crossed immunoelectrophoresis of extracts of iodinated platelets. Secondly, autoradiography of the immunoplates revealed that the

\footnotetext{
${ }^{4}$ Nurden, A. T., D. Depuis, T. Kunicki, and F. P. Caen. Further studies on the glycoprotein and protein composition of Bernard-Soulier platelets. Manuscript in preparation.
}

bulk of the radioactivity was bound to protein 16 . This is in accordance with the observation that GP IIIa becomes most heavily labeled by iodination of platelets (19). Thirdly, protein 16 reacts with Lens culinaris lectin, but not with wheat germ agglutinin (16), and Clemetson and co-workers (37) have shown that GP IIb and, in part, GP IIIa were bound to Lens culinaris lectin. However, neither GP IIb nor GP IIIa was bound to a wheat germ agglutinin-coupled Sepharose column (37). Finally, protein 16 was not detected in type I thrombasthenic platelets, and SDS-PAGE of such platelets has revealed an absence or a markedly reduced PAS stain intensity of the GP IIb and GP IIIa $(8,13)$. The presence of both GP IIb and GP IIIa in precipitate 16 suggests that these glycoproteins may exist together as a complex in the membrane, and that this complex is not broken by the nonionic detergent used to solubilize the platelet proteins. Alternatively, the glycoproteins may have a close affinity for each other and associate after the disruption of the membrane bilayer by the Triton X-100.

IgG-L, the human antibody obtained from a polytransfused thrombasthenic patient, formed an immunoprecipitate with protein 16 . By using a double-immunoprecipitation technique, Degos and co-workers (24) have shown that the IgG-L interacted with a surface component of human platelets with a mol wt of 120,000 but did not identify the nature of this component. The relationship between our results and those of Degos and co-workers (24) is not yet clear, and is the subject of further investigation.

In type I thrombasthenia, no immunoprecipitate was formed with IgG-L, whereas small amounts of protein 16 were precipitated when solubilized proteins from type II thrombasthenic platelets were examined. On the basis of differences in clot retraction and fibrinogen content, Caen (5) introduced the terms type I and type II thrombasthenia. In this investigation we have been able to distinguish between one patient with type II and two patients with type I thrombasthenia, based not only on their fibrinogen content but also on their content of protein 16. Immunological evidence for heterogeneity in thrombasthenia has also been provided by Kunicki and Aster (38), who showed deletion $(<1 \%)$ of the platelet-specific alloantigen $\mathrm{P}^{\mathrm{A} 1}$, in three thrombasthenic patients, whereas two other patients contained 12 and $22 \%$ of the normal values.

The profound functional abnormalities of BernardSoulier and thrombasthenic platelets may be related to the absence of protein 13 and 16, respectively. Further investigation on the properties of these proteins are in progress.

\section{ACKNOWLEDGMENTS}

We would like to acknowledge Miss $H$. de la Baume and D. Depuis for technical assistance, and Mrs. Torill Halvorsen for typing the manuscript. 
This work was supported by Institut de la Santé et de la Recherche Medicale contract number C.R.L. 78. 5.28.1 and Delegation Generale a la Recherche Scientifique et Technique 77.7.0243, Associacion Claude Bernard, The Norwegian Council on Cardiovascular Research, Bloddonernes Forskningsfond, and Kong Christian X's fond.

\section{REFERENCES}

1. Bernard, J., and J.-P. Soulier. 1948. Sur une nouvelle variété de dysthrophie thrombocytaire-hémorragipare congenitale. Sem. Hop. Paris. 24: 3217-3223.

2. Caen, J. P., P. A. Castaldi, J. C. Leclerc, S. Inceman, M. J. Larrieu, M. Probst, and J. Bernard. Congenital bleeding disorders with long bleeding time and normal platelet count. Am. J. Med. 41: 4-26.

3. Hardisty, R. M. Disorders of platelet function. Br. Med. J. 33: 207-212.

4. Lusher, J. M., and M. I. Barnhart. 1977. Congenital disorders affecting platelets. In Seminars in Thrombosis and Haemostasis. E. F. Mammen, editor. Stratton Inter continental Medical Book Corporation, New York. IV: 123-186.

5. Caen, J. P. 1972. Glanzmann's thrombasthenia. Clin. Haematol. 1: 383-392.

6. Grøttum, K. A., and N. O. Solum. 1969. Congenital thrombocytopenia with giant platelets: a defect in the platelet membrane. Br. J. Haematol. 16: 277-290.

7. Caen, J. P., A. T. Nurden, C. Jeanneau, H. Michel, G. Toblem, S. Levy-Toledano, Y. Sultan, F. Valensi, and J. Bernard. 1976. Bernard-Soulier syndrome: a new glycoprotein abnormality. Its relationship with platelet adhesion to subendothelium and with the factor VIII von Willebrand protein. J. Lab. Clin. Med. 87: 586-596.

8. Nurden, A. T., and J. P. Caen. 1977. Further studies on the normal human, Bernard-Soulier and thrombasthenic platelets. Thromb. Haemostasis. 38: 200.

9. Solum, N. O., I. Hagen, and T. Gjemdal. 1977. Platelet membrane glycoproteins and the interaction between bovine factor VIII related protein and human platelets. Thromb. Haemostasis. 38: 914-923.

10. Hagen, I., and N. O. Solum. 1978. Further studies on the protein composition and surface structure of normal platelets and platelets from patients with Glanzmann's thrombasthenia and Bernard-Soulier syndrome. Thromb. Res. 13: 845-855.

11. Jenkins, C. S. P., D. R. Phillips, K. J. Clemetson, D. Meyer, M.-J. Larrieu, and E. F. Luscher. 1976. Platelet membrane glycoproteins implicated in ristocetin-induced aggregation. J. Clin. Invest. 57: 112-124.

12. Nurden, A. T., and J. P. Caen. 1974. An abnormal platelet glycoprotein pattern in three cases of Glanzmann's thrombasthenia. Br. J. Haematol. 28: 253-260.

13. Phillips, D. R., and P. P. Agin. 1977. Platelet membrane defects in Glanzmann's thrombasthenia. J. Clin. Invest. 60: $535-545$.

14. George, J. N., R. K. Morgan, and P. C. Lewis. 1978. Studies on platelet plasma membranes. IV. Quantitative analysis of platelet membrane glycoproteins by $\left({ }^{125} \mathrm{I}\right)$ diazotized diiodosulfanilic acid labeling and SDS-polyacrylamide gel electrophoresis. J. Lab. Clin. Med. 92: $430-446$

15. Bjerrum, O. J. 1977. Immunochemical investigation of membrane proteins. A methodological survey with emphasis placed on immunoprecipitation in gels. Biochim. Biophys. Acta. 472: 135-195.

16. Hagen, I., O. J. Bjerrum, and N. O. Solum. 1979. Charac- terization of Triton X-100 solubilized human platelet proteins by crossed immunoelectrophoresis. Reference patterns of extracts from whole platelets and isolated membranes. Eur. J. Biochem. 99: 9-22.

17. Bernard, J., J. P. Caen, and P. Maroteaux. 1957. La dystrophie thrombocytaire hémorragipare congenitale. Revue Francais d' Hématologié. 12: 222-229.

18. Bøyum, A. 1974. Separation of blood leukocytes, granulocytes and lymphocytes. Tissue Antigens. 4: 269-274.

19. Barber, A J., and Jamieson, G. A. 1970. Isolation and characterization of plasma membranes from human blood platelets. J. Biol. Chem. 245: 6357-6365.

20. Phillips, D. R., and P. P. Agin. 1977. Platelet plasma membrane glycoproteins. Evidence for the presence of nonequivalent disulfide bonds using nonreduced-reduced two dimensional gel electrophoresis. J. Biol. Chem. 252: $2121-2126$

21. Harboe, N., and A. Ingild. 1973. Immunization, isolation of immunoglobulins, estimation of antibody titre. Scand. J. Immunol. 2(Suppl. 1): 161-169.

22. Bjerrum, O. J., and T. C. Bøg-Hansen. 1976. Immunochemical gel precipitation techniques for analysis of membrane proteins. In Biochemical Analysis of Membranes. A. H. Maddy, editor. Chapman \& Hall, London. $379-426$

23. Levy-Toledano, S., G. Tobelem, C. Legrand, R. Bredoux, L. Degos, A. Nurden, and J. P. Caen. 1978. Acquired IgG antibody occurring in a polytransfused thrombasthenic patient: its effect on human platelet function. Blood. 51: 1065-1071.

24. Degos, L., A. Dautigny, J. C. Brouet, M. Colombani, N. Ardaillou, J. Caen, and J. Colombani. 1975. A molecular defect in thrombasthenic platelets. J. Clin. Invest. 56: 235-240.

25. Weeke, B. 1973. General remarks on principles, equipment, reagents and procedures. Scand. J. Immunol. 2 (Suppl. 1): 15-35.

26. Laemmli, V. K. 1970. Cleavage of structural proteins during the assembly of the head of bacteriophage T4. Nature (Lond.). 227: 680-685.

27. Norrild, B., O. J. Bjerrum, and B. F. Vestergård. 1977. Polypeptide analysis of individual immunoprecipitates from crossed immunoelectrophoresis. Anal. Biochem. 81: $432-441$.

28. Fairbanks, G., T. L. Steck, and D. F. H. Wallach. 1971. Electrophoretic analysis of the major polypeptides of the erythrocyte membrane. Biochemistry. 10: 2606-2616.

29. Zacharius, R. M., T. E. Tell, J. H. Morrison, and J. J. Woodlock. 1969. Glycoprotein staining following electrophoresis on acrylamide gels. Anal. Biochem. 30: 148-152.

30. Solum, N. O., I. Hagen, and M. Peterka. 1977. Human platelet glycoproteins. Further evidence that the "GP I band" from whole platelets contains the different polypeptides one of which may be involved in the interaction between platelets and factor VIII. Thromb. Res. 10: 71-82.

31. Hagen, I., A. T. Nurden, O. J. Bjerrum, N. O. Solum, and J. P. Caen. 1979. Immunochemical difference between type I and type II thrombasthenic platelets. In Colloquim Protides of the Biological Fluids. XXVII Colloquium May 1979. H. Peeters, editor. Pergamon, Oxford, England. In press.

32. Bock, E., and C. Bræestrup. 1978. Regional distribution of the synaptic membrane proteins: synaptin, D1, D2 and D3. J. Neurochem. 30: 1603-1607.

33. Okumura, T., and G. A. Jamieson. 1976. Platelet glycocalicin I. Orientation of glycoproteins of the human platelet surface. J. Biol. Chem. 251: 5944-5949. 
34. Bjerrum, O. J., K. B. Helle, and E. Bock. 1979. Immunochemically identical hydrophilic and amphiphilic forms of the bovine adrenomedullary dopamine $\beta$-hydroxylase. Biochem. J. 181: 231-237.

35. Nachman, R. L., T. Kinoshita, and B. Ferris. 1979 Structural analysis of human platelet membrane glycoprotein I complex. Proc. Natl. Acad. Sci. U. S. A. 76: 2952-2954.

36. Jamieson, G. A., T. Okumura, B. Fishback, M. M. Johnson. J. J. Egan, and H. J. Weiss. 1979. Platelet membrane glycoproteins in thrombsthenia, Bernard-Soulier syndrome and storage pool disease. J. Lab. Clin. Med. 93: 652-660.

37. Clemetson, K. J., S. L. Pfueller, E. F. Luscher, and C. S. P. Jenkins. 1977. Isolation of the membrane glycoproteins of human blood platelets by lectin affinity chromatography. Biochim. Biophys. Acta. 464: 493-508.

38. Kunicki, T. J., and R. H. Aster. 1978. Deletion of the platelet-specific alloantigen $\mathrm{P}^{\mathrm{A} 1}$ from platelets in Glanzmann's thrombasthenia. J. Clin. Invest. 61: 1225-1231. 